\title{
Phytoprotection
}

\section{Differences in virulence of Diplocarpon earlianum isolates on selected strawberry cultivars}

\author{
A.G. Xue, J.C. Sutton, A. Dale et J.A. Sullivan
}

Volume 77, numéro 3, 1996

URI : https://id.erudit.org/iderudit/706107ar

DOI : https://doi.org/10.7202/706107ar

Aller au sommaire du numéro

Éditeur(s)

Société de protection des plantes du Québec (SPPQ)l

ISSN

0031-9511 (imprimé)

1710-1603 (numérique)

Découvrir la revue

Citer cet article

Xue, A., Sutton, J., Dale, A. \& Sullivan, J. (1996). Differences in virulence of Diplocarpon earlianum isolates on selected strawberry cultivars. Phytoprotection, 77(3), 113-118. https://doi.org/10.7202/706107ar
Résumé de l'article

Huit isolats de Diplocarpon earlianum ont été évalués sur 18 cultivars de fraisiers (Fragaria x ananassa) pour leur virulence, laquelle a été mesurée par leur capacité de causer un pourcentage de surface foliaire portant des symptômes. Des différences significatives ont été observées entre les isolats et les cultivars, ainsi que pour l'interaction isolat x cultivar. Quatre des huit isolats, sur la moyenne des 18 cultivars de fraisiers, avaient une surface foliaire portant des symptômes de 6,7-9,6 \% et ils ont été classifiés dans le groupe defaible virulence. Les quatre autres isolats avaient une surface portant des symptômes variant de $25,9-45,8$ \% et formaient un groupe de forte virulence. Parmi les cultivars testés, 'Vibrant' était résistant et 'Micmac' était susceptible à tous les isolats dans les deux groupes de virulence; 'Honeyoye', 'Redcoat', 'Scotland', 'St. Clair' et 'Vantage' étaient résistants au groupe de faible virulence, mais ils présentaient des interactions différentielles envers les isolats du groupe de forte virulence, les 11 autres cultivars étaient sensibles au groupe de forte virulence mais ils démontraient des interactions différentielles envers les isolats du groupe de faible virulence. Il est suggéré que plusieurs isolats de l'agent pathogène soient requis pour tester des génotypes de fraisiers pour leur résistance à la tache pourpre. Une méthode d'essai utilisant des disques foliaires a été développée et elle peut être utilisée pour évaluer la susceptibilité de génotypes de fraisiers au $D$. earlianum en laboratoire.
Ce document est protégé par la loi sur le droit d'auteur. L’utilisation des services d'Érudit (y compris la reproduction) est assujettie à sa politique d'utilisation que vous pouvez consulter en ligne.

https://apropos.erudit.org/fr/usagers/politique-dutilisation/ 


\title{
Differences in virulence of Diplocarpon earlianum isolates on selected strawberry cultivars
}

\author{
Allen G. Xue ${ }^{1}$, John C. Sutton², Adam Dale ${ }^{3}$, and \\ J. Alan Sullivan ${ }^{4}$
}

Received 1996-01-19; accepted 1996-10-03

Eight isolates of Diplocarpon earlianum were evaluated for virulence, measured as the ability to produce percent leaf area with symptoms (LAS), on 18 cultivars of strawberry (Fragaria $x$ ananassa). Significant differences were observed from isolate and cultivar effects, and isolate $x$ cultivar interaction. Four of the eight isolates, on the average of 18 strawberry cultivars, had LAS ranging from $6.7-9.6 \%$, and were classified as a group of low virulence. The remaining four isolates had LAS ranging from $25.9-45.8 \%$ and formed a high virulence group. Of the cultivars tested, 'Vibrant' was resistant and 'Micmac' was susceptible to all isolates in both virulence groups; 'Honeoye', 'Redcoat', 'Scotland', 'St. Clair' and 'Vantage' were resistant to the low virulence group, but had differential interactions to isolates in the high virulence group; the remaining 11 cultivars were susceptible to the high virulence group, but had differential interactions to isolates in the low virulence group. It is suggested that a number of different pathogen isolates are required to test strawberry genotypes for leaf scorch resistance. A leaf disk assay was developed in this study and can be used for laboratory evaluations of strawberry genotypes for susceptibility to $D$. earlianum.

Xue, A.G., J.C. Sutton, A. Dale et J.A. Sullivan. 1996. Variation de la virulence d'isolats de Diplocarpon earlianum sur certains cultivars de fraisiers. PHYTOPROTECTION 77 : 113-118.

Huit isolats de Diplocarpon earlianum ont été évalués sur 18 cultivars de fraisiers (Fragaria $\mathrm{x}$ ananassa) pour leur virulence, laquelle a été mesurée par leur capacité de causer un pourcentage de surface foliaire portant des symptômes. Des différences significatives ont été observées entre les isolats et les cultivars, ainsi que pour l'interaction isolat $x$ cultivar. Quatre des huit isolats, sur la moyenne des 18 cultivars de fraisiers, avaient une surface foliaire portant des symptômes de 6,7-9,6\% et ils ont été classifiés dans le groupe de faible virulence. Les quatre autres isolats avaient une surface portant des symptômes variant de $25,9-45,8 \%$ et formaient un groupe de forte virulence. Parmi les cultivars testés, 'Vibrant' était résistant et 'Micmac' était susceptible à tous les isolats dans les

1. Agriculture and Agri-Food Canada, Morden Research Centre, Morden, Manitoba, Canada R6M $1 Y 5$

2. Department of Environmental Biology, University of Guelph, Guelph, Ontario, Canada N1G 2W1

3. Horticultural Research Institute of Ontario, Horticultural Experiment Station, Simcoe, Ontario, Canada N3Y 4N5

4. Department of Horticultural Science, University of Guelph, Guelph, Ontario, Canada N1G 2W1 
deux groupes de virulence; 'Honeyoye', 'Redcoat', 'Scotland', 'St. Clair' et 'Vantage' étaient résistants au groupe de faible virulence, mais ils présentaient des interactions différentielles envers les isolats du groupe de forte virulence, les 11 autres cultivars étaient sensibles au groupe de forte virulence mais ils démontraient des interactions différentielles envers les isolats du groupe de faible virulence. Il est suggéré que plusieurs isolats de l'agent pathogène soient requis pour tester des génotypes de fraisiers pour leur résistance à la tache pourpre. Une méthode d'essai utilisant des disques foliaires a été développée et elle peut être utilisée pour évaluer la susceptibilité de génotypes de fraisiers au D. earlianum en laboratoire.

\section{INTRODUCTION}

Leaf scorch, caused by Diplocarpon earlianum (Ell. and Ev.) Wolf, is a major foliar disease of strawberry (Fragaria $x$ ananassa Duch.) in Ontario (Evans et al. 1988; Zheng and Sutton 1994). The disease often results in severe loss of photosynthetic leaf area during September and October, and reduced vegetative growth and fruit yield in the subsequent crop season (Mutisya 1994; Mutisya et al. 1992; Stone 1922). Fungicide sprays have been recommended to control leaf scorch (OMAF 1992) but fungicide use is threatened by growing public opposition. Host resistance is a preferred method of disease control, however, cultivars combining leaf scorch resistance with high fruit yield and quality are not yet commercially available. The development of resistant cultivars requires identification of sources of resistance and an understanding of variation in virulence in populations of $D$. earlianum. Currently, information on host resistance and pathogen virulence is sparse. The objectives of the present study were to develop a rapid and reliable inoculation method, and to use this method to examine the pathogenic variation of different $D$. earlianum isolates on selected strawberry cultivars.

\section{MATERIALS AND METHODS}

\section{Strawberry plants}

Eighteen virus-free cultivars (Table 1) were propagated in screenhouses at the Horticultural Research Institute of Ontario, Vineland Station (lat. $43^{\circ} 12^{\prime} \mathrm{N}$, long. $79^{\circ} 24^{\prime}$ W), Ontario, and stored over winter at 0 to $-2^{\circ} \mathrm{C}$. In the spring, the plants were transplanted to $12-\mathrm{cm}$ diam pots containing a mixture of loam, sand, and composted horse manure (1:1:1 $\mathrm{vol}$ : vol : vol) and maintained at $25 \pm 1^{\circ} \mathrm{C}$ during the day and $20 \pm 1^{\circ} \mathrm{C}$ at night in a greenhouse. Supplemental light was provided by $300-\mathrm{W}$ metal halide lamps, to ensure a 16-h photoperiod and a minimum irradiance of $360 \mu \mathrm{mol} \cdot \mathrm{m}^{-2} \cdot \mathrm{s}^{-1}$. Plants were supplied with a $1 \%$ solution of 20-20-20 (N-P-K) fertilizer 4 wk after transplanting, and inoculated at $6 \mathrm{wk}$ when each plant had four expanded green leaves.

\section{Pathogen isolates}

$D$. earlianum was isolated from diseased strawberry leaves collected in 1991 at eight locations including: Acton (lat. $43^{\circ} 39^{\prime} \mathrm{N}$, long. $80^{\circ} 3^{\prime} \mathrm{W}$ ), Arkell (lat. $43^{\circ} 34^{\prime} \mathrm{N}$, long. $80^{\circ} 16^{\prime} \mathrm{W}$ ), Cambridge (lat. $43^{\circ} 22^{\prime} \mathrm{N}$, long. $80^{\circ} 19^{\prime} \mathrm{W}$ ), Elora (lat. $43^{\circ} 38^{\prime} \mathrm{N}$, long $80^{\circ} 25^{\prime} \mathrm{W}$ ), Simcoe (lat. $42^{\circ} 45^{\prime} \mathrm{N}$, long. $80^{\circ} 19^{\prime} \mathrm{W}$ ), and Vineland in Ontario, Kentville in Nova Scotia (lat. $45^{\circ} 5^{\prime} \mathrm{N}$, long. $64^{\circ} 29^{\prime} \mathrm{W}$ ), and Puyallup (lat. $47^{\circ} 12^{\prime} \mathrm{N}$, long. $121^{\circ} 18^{\prime} \mathrm{W}$ ) in Washington, USA. Single spore isolates from the respective locations were given the corresponding prefixes AC, AR, CA, EL, SI, VI, NS and WA, plus an identification number (Table 1). To isolate the pathogen, pieces of leaves (about $4 \mathrm{~mm}^{2}$ ) with leaf scorch symptoms were surface sterilized in $1 \%$ sodium hypochlorite for $90 \mathrm{~s}$, rinsed in sterile distilled water, placed on bean pod extract-sucrose-malt extract agar (BSMA) (Dhanvantari 1967) in 9-cm diam petri dishes, and incubated at $20^{\circ} \mathrm{C}$ beneath cool-white fluorescent lamps operated on a 14-h photoperiod for $21 \mathrm{~d}$. Spores from small (about $4 \mathrm{~mm}$ diam) pinkish colonies of $D$. earlianum that developed from the leaf pieces were suspended in drops of sterile distilled water, spread on fresh BSMA, and incubated as described above for $24 \mathrm{~h}$. Germinated spores were indi- 
Table 1. Severity of leaf scorch, measured as percent leaf area with symptoms (LAS), produced by eight isolates of Diplocarpon earlianum on 18 cultivars of strawberry using leaf disk assay and the corresponding analysis of variance

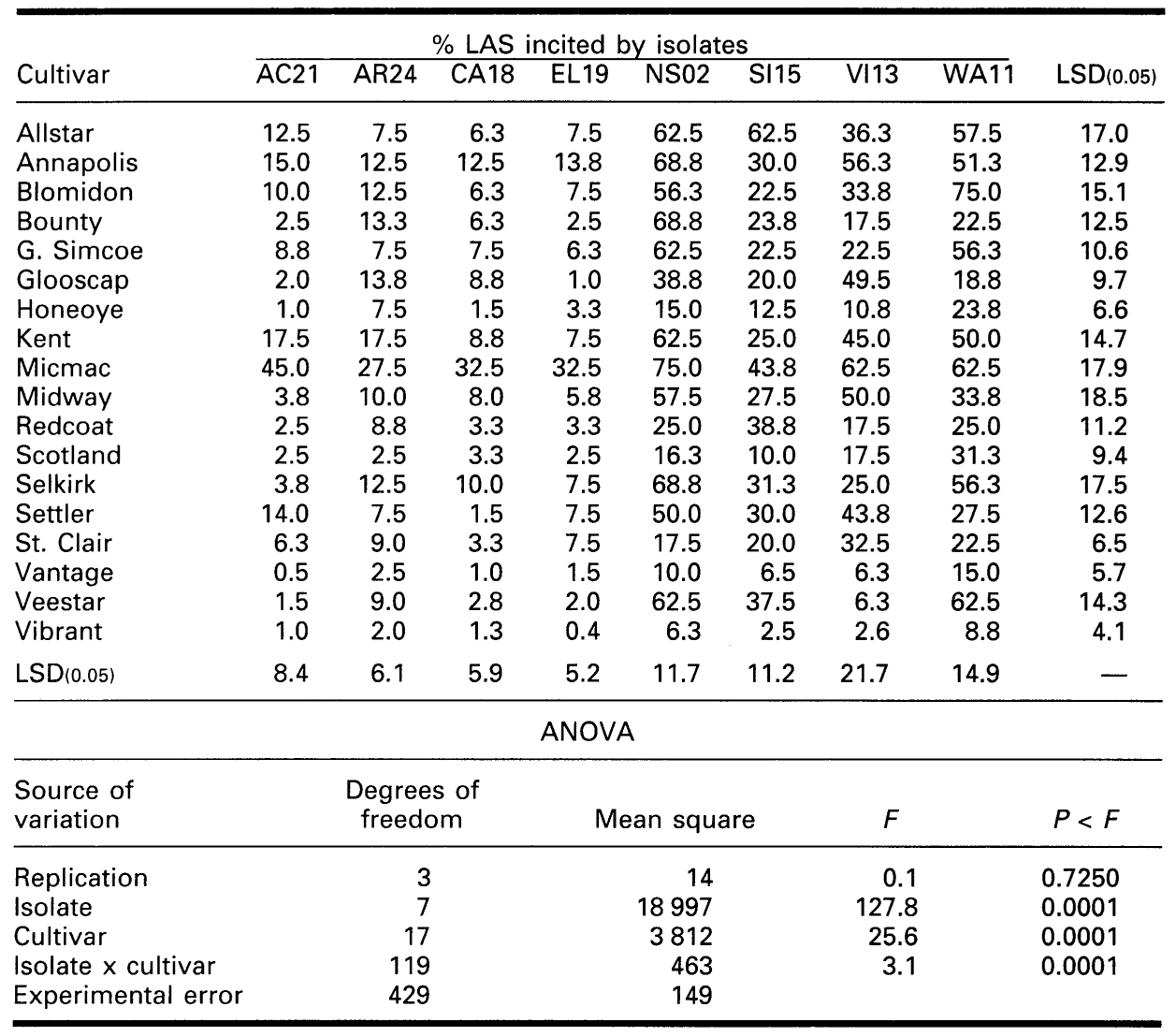

vidually transferred to BSMA slants and incubated in the same conditions for 4 wk. The isolates were maintained on BSMA at $1-4^{\circ} \mathrm{C}$ and transferred at 3-mo intervals.

\section{Inoculum preparation and inoculations}

Conidia from 4-wk-old cultures on BSMA were recovered in sterile distilled water plus surfactant ( $1 \mathrm{~mL}$ Triton $X R \mathrm{~L}^{-1}$ water), shaken vigorously, filtered through two layers of cheesecloth, counted with the aid of a hemacytometer and diluted to $10^{4}$ conidia $\mathrm{mL}^{-1}$ for inoculations. Prior to each inoculation, percent germination of conidia was estimated on $2 \%$ water agar and was found to consistently exceed $80 \%$. Plants were inoculated with $0.4 \mathrm{~mL}$ of inoculum per plant using a DeVilbiss model 15 atomizer (The DeVilbiss Co., Somerset, Pennsylvania), allowed to dry for $30 \mathrm{~min}$, placed in polyethylene humidity chambers in darkness at $20^{\circ} \mathrm{C}$ for $24 \mathrm{~h}$, and subsequently moved to a growth room with a $14-\mathrm{h}$ photoperiod at $20^{\circ} \mathrm{C}$. Humidity in the chamber was maintained at or near saturation by continuous operation of an ultrasonic humidifier. Air temperature and humidity in the chamber, monitored with a hygrothermograph (model 252, Lambrecht, Gottingen, Germany), were $20 \pm 1^{\circ} \mathrm{C}$ and $100 \% \mathrm{RH}$, respectively.

\section{Disease assessment}

Severity of leaf scorch was assessed on each leaf disk $14 \mathrm{~d}$ after inoculation when the disease development reached the maximum level in the leaf disk assay, and on the top three inoculated leaves $19 \mathrm{~d}$ after inoculation in the whole plant method. The disease severity was estimated visually and the observations were 
classified in eight categories of a scale modified from Horsfall and Cowling (1978). The eight categories were 0\% (median value $=0 \%$ ) of leaf area with symptoms (LAS); < 1\% LAS (median value $=0.5 \%) ; 1-5 \%$ LAS (median value $=$ $2.5 \%$ ); $6-10 \%$ LAS (median value $=7.5 \%$ ); $11-25 \%$ LAS (median value $=17.5 \%$ ); $26-50 \%$ LAS (median value $=37.5 \%$ ); $51-75 \%$ LAS (median value $=62.5 \%$ ); and $>75 \%$ LAS (median value $=87.5 \%$ ). The mean LAS values of leaves (disks) in a replicated treatment were calculated using Equation 1.

LAS $=\frac{\sum \text { (median value } x \text { no. leaves (disks) in category) }}{\text { Total no. leaves (disks) }}$

\section{Resistance assays}

Resistance of strawberry cultivars to $D$. earlianum was evaluated by means of a leaf disk assay and a whole plant method. Eight cultivars (Blomidon, Honeoye, Kent, Micmac, Redcoat, Scotland, Vantage and Veestar) and isolate AR24 of $D$. earlianum were used. For the leaf disk assay, disks were cut from the mid-portion of leaflets that were 14-21 d past bud stage. Ten leaf disks, taken at random, were placed on a fiberglass screen $11 \mathrm{~mm}$ mesh), which overlaid four layers of sterilized paper towel moistened with sterilized water, in each of four replicate petri dishes per cultivar. Each disk was inoculated with $0.02 \mathrm{~mL}$ of conidial suspension plus surfactant using the DeVilbiss model 15 atomizer. The dishes were immediately sealed with Parafilm ${ }^{\circledast}$ and placed beneath cool-white fluorescent lamps plus incandescent lamps $(150 \mu \mathrm{mol}$ $\mathrm{m}^{-2} \cdot \mathrm{s}^{-1}, 14-\mathrm{h}$ photoperiod) at $20^{\circ} \mathrm{C}$. In the whole plant method, four plants of each cultivar were inoculated with spore suspension as described previously. A randomized complete block design was used for both methods and the experiments were repeated twice.

\section{Isolate-cultivar interactions}

Leaf disk assay was used to evaluate virulence of eight isolates of $D$. earlianum on 18 cultivars of strawberry (Table 1). Leaf disks were cut from leaves that were 14-21 d past the bud stage. Each isolatecultivar combination in a replicate was represented by four petri dishes and 10 disks per petri dish. The experiments were arranged in a randomized complete block design.

\section{Statistical analyses}

Analysis of variance was conducted using the statistical analysis system (SAS Institute Inc. 1987) for differences among isolates and cultivars, and for the isolate $x$ cultivar interaction. Pearson correlation analysis (Snedecor and Cochran 1980) was used for determining the reliability of the leaf disk assay in relation to the whole plant method.

\section{RESULTS AND DISCUSSION}

Both the leaf disk assay and the whole plant method were effective in identifying the differences among the eight cultivars in reaction to isolate AR24 of $D$. earlianum (Fig. 1). In both assays, cultivars 'Vantage' and 'Scotland' were the most resistant while 'Kent' and 'Micmac' were the most susceptible; and 'Blomidon', 'Honeoye', 'Redcoat' and 'Veestar' were of intermediate resistance. Correlation between the two methods was significant $(r=0.861, P<0.05)$. Compared with the whole plant method, leaf disk

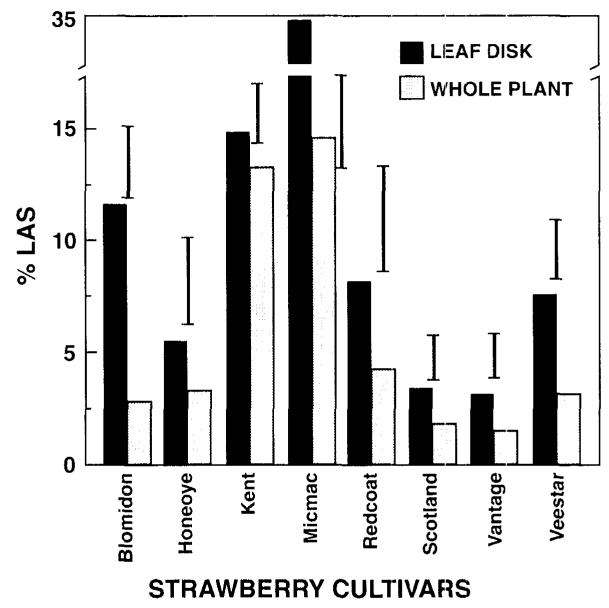

Figure 1. Comparative evaluation of eight strawberry cultivars in resistance to leaf scorch using leaf-disk assay and whole-plant method. Vertical bars indicate LSD values at $P \leq 0.05$. LAS : Leaf area with symptoms. 
assay induced a greater amount of damage for all eight cultivars of strawberry. On susceptible cultivars, lesions on leaf disks often coalesced shortly after they appeared and resulted in large areas of leaf necrosis at the time of assessment. The higher level of disease produced with the leaf disk assay would facilitate screening of genotypes for leaf scorch resistance.

LAS values obtained from leaf disk assay of 18 strawberry cultivars with eight $D$. earlianum isolates are presented in Table 1. Analysis of variance showed highly significant differences due to both $D$. earlianum isolate and strawberry cultivar effects. The isolate $x$ cultivar interaction was also highly significant. However, the sum of mean square value (463) from this source of variation was only $2.4 \%$ compared to that of isolates (18 997) and $12.1 \%$ of cultivars (3812). This indicated that the contribution of isolate $x$ cultivar interaction to the variability was low and not enough to differentiate pathotypes among the isolates tested. Differences among replicates were not significant.

From data on virulence rating of each $D$. earlianum isolate toward the 18 strawberry cultivars, the eight isolates clearly fell into two groups. Isolates EL19, CA18, AC21 and AR24 had LAS of 6.7, 6.9, 8.3, and $9.6 \%$, respectively, and formed a group of relatively low virulence; while isolates WA11, VI13, SI15 and NS02 had LAS of $25.9,29.7,38.8$, and $45.8 \%$, respectively, and formed a group of high virulence. Different reactions were observed for the 18 cultivars to isolates in the two virulence groups. 'Vibrant' had LAS ranging from $0.4-8.8 \%$ to the eight isolates and was considered resistant to both virulence groups. 'Micmac', which had LAS ranging from $27.5-75.0 \%$ to all isolates, was considered susceptible to both virulence groups. 'Honeoye', 'Redcoat', 'Scotland', 'St. Clair' and 'Vantage' had LAS ranging from $1.0-9.0 \%$ to isolates in low virulence group and LAS of $6.3-38.8 \%$ to isolates in high virulence group. These five cultivars were considered resistant to isolates in low virulence group, and had differential interactions to isolates in the high virulence group. The remaining 11 cultivars had LAS of
$17.5-68.8 \%$ to isolates in high virulence group and LAS of $1.0-17.5 \%$ to isolates in low virulence group. These cultivars were susceptible to isolates in high virulence group and had differential interactions to isolates in the low virulence group.

This study demonstrated the existence of variation in virulence among $D$. earlianum isolates and in resistance reactions of strawberry cultivars to these isolates. The different levels of virulence of $D$. earlianum isolates do not appear strongly related to the susceptibility of strawberry cultivars. Leaf scorch symptoms incited by low virulence isolates developed slowly in all cultivars compared to those from inoculations by high virulence isolates. On the other hand, although all strawberry cultivars became more susceptible when challenged with high virulence isolates, some cultivars such as 'Vibrant' in particular, expressed low levels of disease severity (LAS ranging from $2.5-8.8 \%$ ). These results suggest that different resistance mechanisms may be involved in the host-pathogen relationships. The cultivar 'Vibrant' may carry some resistance genes capable of reducing the development of leaf scorch by both types of virulence isolates. This cultivar will be a useful source for the development of stable resistance to leaf scorch.

The findings of pathogenic variation of naturally occurring $D$. earlianum isolates was supported by an earlier research carried out by Strobbe (1968), who recognized pathogenic specialization in two isolates of $D$. earlianum. The presence of isolate $x$ cultivar interactions has practical implications that must be considered in breeding and screening strawberry genotypes for leaf scorch resistance. Genotypes with a resistant reaction to a single isolate of the pathogen may not express resistance when challenged by the natural field populations of $D$. earlianum. The process of screening for resistance, therefore, requires a number of different pathogen isolates to be included in the test. Similarly, it is also not possible to compare the level of resistance among strawberry genotypes without referring to the virulence of pathogen isolates used. Further studies on hostpathogen relationship are needed to 
determine the cultural and biochemical parameters causing different degrees of virulence, and the possible occurrence of pathotypes or races, in populations of $D$. earlianum.

Screening of strawberry cultivars and genotypes for leaf scorch resistance has been conducted conventionally in the field (Converse et al. 1981; Janick and Williams 1959; Scott et al. 1969). Field evaluation can undoubtedly reveal reactions of cultivars to local pathogen populations, but is inadequate when the virulence of the pathogen is variable and has differential interactions with host genotypes. Greenhouse tests of whole plants to evaluate resistance of strawberry to leaf scorch (Dhanvantari 1967) are timeconsuming and costly when large numbers of plants and isolates are tested. Compared to field and greenhouse methods, the leaf disk assay developed in this study is more economical in terms of space, time and labor. In addition, leaf disk assay can be conducted throughout the year and individual plants can be tested repeatedly by multiple sampling of leaves. The leaf disk assay should facilitate a rapid evaluation of a large number of plants to different $D$. earlianum isolates in breeding programs.

\section{ACKNOWLEDGEMENTS}

The financial support of the Ontario Ministry of Agriculture and Food (OMAF) Food Systems 2002 Pest Management Research Program (Project F57062), and of the OMAF-University of Guelph Research Contract, is gratefully acknowledged.

\section{REFERENCES}

Converse, R.H., W.C. Denison, and F.J. Lawrence. 1981. Reaction of some Pacific Coast strawberry cultivars to leaf scorch. Plant Dis. 62 : 254-255.

Dhanvantari, B.N. 1967. The leaf scorch disease of strawberry (Diplocarpon earlianum) and the nature of resistance to it. Can. J. Bot. 45 : 1525-1543.
Evans, W.D., A. Dale, and C. Hunter. 1988. The strawberry in Ontario. Ontario Ministry of Agriculture and Food. Publication 513. Queen's Printer for Ontario. Toronto, Ontario. $30 \mathrm{pp}$.

Horsfall, J.G., and E.B. Cowling. 1978. Phytopathometry: the measurement of plant disease. Pages 120-135 in J.G. Horsfall and E.B. Cowling (eds.), Plant disease : an advanced treatise, Vol. 2. Academic Press, New York.

Janick, J., and E.B. Williams. 1959. Resistance of strawberry varieties and selections to leaf spot and scorch. Plant Dis. Rep. 43 : 413-415.

Mutisya, J.M. 1994. Relationship between leaf scorch (Diplocarpon earlianum) and yield in strawberry. M.Sc. thesis, University of Guelph. 137 pp.

Mutisya, J.M., J.A. Sullivan, S. Couling, and J.C. Sutton. 1992. Effect of leaf scorch on yield of Kent strawberry. Can. J. Plant Sci. 72 : 1292 (Abstract).

OMAF. 1992. Fruit production recommendations. Ontario Ministry of Agriculture and Food. Publication $360.92 \mathrm{pp}$.

SAS Institute Inc. 1987. SAS/STAT guide for personal computers. Version 6. SAS Institute Inc., Cary, North Carolina 1028 pp.

Scott, D.H., A.D. Draper, J.R. McGrew, and I.C. Haut. 1969. Resistance of strawberry varieties to leaf scorch disease. Plant Dis. Rep. 53 : 16-18.

Snedecor, G.W., and W.G. Cochran. 1980. Statistical methods. $7^{\text {th }}$ ed. The lowa State Univ. Press. Ames, lowa, 507 pp.

Stone, R.E. 1922. Leaf scorch or Mollisiose of the strawberry. Phytopathology 12 : 375-380.

Strobbe, M.A. 1968. A study and differentiation of two isolates of Diplocarpon earlianum (Ell. \& Ev.) Wolf. Diss. Abstr. 28 : 4838. Univ. of Illinois.

Zheng, J., and J.C. Sutton. 1994. Inoculum concentration, leaf age, wetness duration, and temperature in relation to infection of strawberry leaves by Diplocarpon earlianum. Can. J. Plant Pathol. 16 : 17/7-186. 